\title{
GEOGRAPHICAL ANALYSIS OF GEOTOURISM BASED SEASONAL ECONOMY IN LAHAUL AND SPITI, HIMACHAL PRADESH (INDIA)
}

\author{
KRISHNANAND* \\ Department of Geography, Shaheed Bhagat Singh College, University of Delhi, \\ Sheikh Sarai Phase -II, New Delhi -110017, India, e-mail: lovingkrishna@gmail.com \\ V.A.V RAMAN \\ Department of Geography, Shaheed Bhagat Singh College, University of Delhi, \\ Sheikh Sarai Phase -II, New Delhi -110017, India, e-mail: ramanvav@gmail.com
}

\begin{abstract}
Citation: Krishnanand, \& Raman, V.A.V. (2019). GEOGRAPHICAL ANALYSIS OF GEOTOURISM BASED SEASONAL ECONOMY IN LAHAUL AND SPITI, HIMACHAL PRADESH (INDIA). GeoJournal of Tourism and Geosites, 24(1), 118-132. https://doi.org/10.30892/gtg.24110-347
\end{abstract}

\begin{abstract}
Geotourism is a segment of tourism that has developed and gained significance worldwide in recent years. It is of paramount significance in the transhimalayan region that has diversity of geomorphosites located amidst extreme climatic conditions being geophysical stimuli leading to seasonality embedded in human response. The aim of this work is to provide geographical analysis of seasonal economy based on geomorphosites and associated geotourism in the study area in 2017-18. The research is based on field work and qualitative research methods together with remote sensing, GIS and GPS for spatial analysis. The result shows that Langza village is the most significant geotourist site in Spiti valley having fossil abundance and exposure, fostering geotourism. The site needs to be protected and regulated by creating a fossil park, in order to harness the tremendous potential of geotourism and thereby boosting the seasonal economy.
\end{abstract}

Key words: Geotourism, Lahaul and Spiti, Seasonal Economy, Geotourism, Geomorphosites

\section{INTRODUCTION}

Geotourism is emerging as a new global phenomenon (Dowling, 2008a). It is a recent branch of tourism that has emerged from the ideas of nature conservation insitu. It is sustainable tourism with a primary focus on experiencing the earth's geological features in a way that fosters environmental and cultural understanding, appreciation and conservation, and is locally beneficial (Dowling \& Newsome, 2006). It is about creating a geotourism product that protects geoheritage, helps build communities, communicates and promotes geological heritage and works with a wide range of different people.

\footnotetext{
* Corresponding author
} 
According to James and Hose (2008), geotourism is a form of special interest tourism and focuses on geology and the formation of landscapes. It needs awareness for Geological and Geomorphological heritage. According to Dowling (2011), "geological/ geomorphological tourism" includes two aspects. The geological element focuses on geology and landscape. It consists of 'form', such as landforms, rock outcrops, rock types, sediments, soils and crystals, and also 'process', such as volcanism, erosion, glaciation etc.

The other element, that is tourism, includes tourists visiting, learning from, appreciating and engaging in geosites/geomorphosites. Geomorphosite term was first proposed in 1993 by M.Panniza. According to Panizza, a geomorphosite represents " $a$ landform to which a value can be attributed" (Panizza, 2001, p.4) - a very brief definition that allowed a wide range of values to be associated to geomorphosites, from scientific and ecological, to aesthetic, cultural and economical. The definition was later clarified by E. Reynard who separated the central - scientific - value from the additional ones (Reynard, 2005). Landforms are potential resources for geotourism which, following the assessment of their scientific value, become steady resources or "geomorphosites". As an adequate management framework is implemented (hereby including good quality infrastructure, general and specific services and facilities), geomorphosites become authentic geotourism products (Neches, 2013). Geomorphosites are also defined as the geomorphological landforms which have gained scientific, historical, cultural, aesthetic or socioeconomic value due to human knowledge and exploitation (Shayan et al. 2011). Therefore, geomorphosites in combination with cultural, historical and ecological heritage would havegreat potential in the development of sustainable tourism (Coratza et al., 2008, 107).

Geological and geomorphological processes with high scientific and educational interest can be associated to aesthetics/monumentality and become geomorphosites or geosites with tourist potential. Geomorphosites based tourism can be defined as the science of studying geomorphosites or the special geomorphic landscapes which benefit scientific, ecological, cultural, aesthetic and economic value simultaneously (Pereira et al., 2007). Hence, both geological and geomorphological features are of paramount importance in understanding geotourism. Yamani et al., (2012) studied the tourism potentials of some geomorphosite of Guilan province applying Pralong and Pereira models and suggest that among the studied geomorphosites, raised beaches got the highest score and muds got the lowest score in tourism development. Geotourism is intended to stimulate the knowledge of geodiversity, geoconservation and use them for sustainable development. Now, looking at "geodiversity", it may be defined simply as the natural range (diversity) of geological (rocks, minerals, fossils), geomorphological (land form, physical processes) and soil features. It includes their assemblages, relationships, properties, interpretations and systems (Gray, 2004). Geotourism tends to explore the establishment of geoparks as high quality destinations for alternative sustainable tourism, to promote recent developments in protection and promotion of natural heritage in combination with local development as well as in management and operation of Geoparks.

According to Dowling (2011), there are five key principles which are fundamental to geotourism. a) It is geologically-based (that is, based on the earth's geoheritage), b) sustainable (i.e.: economically viable, community enhancing and fosters geoconservation), c) educative (achieved through geo-interpretation), d) locally beneficial and e) generates tourist satisfaction. It is imperative that the first three principles are considered to be essentially present for a function to be known as 'geotourism' where as the last two principles are considered desirable for all forms of tourism. Thus, geotourism may be initiated in any region as educational tourism so that it can be one of the most powerful tools for protecting the environment (Hassan et al., 2012). 
Geotourism may be further described as having a number of essential characteristics. These elements combine to shape geotourism in its present form as discussed across the globe. It comprises a number of interrelated components all of which should be present for authentic geotourism to emerge as a function of landscape. In other words, geomorphotourism is one domain of earth science studies and it studies of tourism that focuses on identifying geomorphosites or especial prospects of geomorphology. By combining cultural, historical and ecological heritage, this area offers a great potential in planning of regional sustainable tourism (Fakhri et al., 2013). A better understanding of the earth with reference to its geological attraction is thegoal of geotourism which arises from the motivation of enjoying unique features amidst of landscape (Adriansyah et al., 2015). In their study, Pica et al., (2016) enhanced geotourism in the city centre, by describing the palaeogeography of ancient Rome through the landforms that were still visible and identified two geomorphosites. In their investigative attempt, Pica, et al., (2016) developed an evaluation model of the geotouristic value of a Site (VSG index), which consisted of the quantification of five fundamental attributes for a geosite, characterizing its scientific and geotourist interests.

\section{STUDY AREA}

Lahaul and Spiti district of Himachal Pradesh, India (Figure 1) is a land of mountain passes that act as gateway for outsiders as well as the locals. The district has an inherent seasonality in character due to the seasonal opening of mountain passes and thereby exchange of goods and services during this fixed time period. The Rohtang pass, Kunzum pass and the Baralacha pass are the most important among all the passes in the district. Rohtang pass in the eastern Pir-Panjal range of greater Himalaya, connects Kullu district to lahaul and Spiti district while Baralacha pass is the gateway from lahaul to Ladakh and Kunzum pass connects the Lahaul and Spiti tehsils. Hence, these passes facilitate inter-district as well as intra-district accessibility for tourists and locals both. The tentative time period of opening of these passes vary between $2 \mathrm{O}^{\text {th }}$ May to $5^{\text {th }}$ June every year depending upon the climatic conditions and they close by $15^{\text {th }}$ October. Therefore, the season for various activities including business and tourism is confined to these four months of June, July, August and September.

Lahaul and Spiti district falls in the rain shadow area of the Great Himalayan Range and thereby restricts the monsoon winds to traverse through and keeps the district dry and gives it a cold desert character. In Lahaul valley, annual rainfall varies from about 10 to $40 \mathrm{~cm}$. Southern and south western part of the Lahaul receives higher rainfall as compared to northern part. In Lahaul valley snowfall varies from less than 1 $\mathrm{m}$ to $6 \mathrm{~m}$ and may be higher at higher altitudes. Maximum temperature at Keylong (headquarter) ranges between $7^{\circ} \mathrm{C}$ and $23^{\circ} \mathrm{C}$ while minimum temperature from $-10^{\circ} \mathrm{C}$ to $+10^{\circ} \mathrm{C}$ in the month of February and July respectively. As per 2011 census, entire 100 per cent population of Lahaul and Spiti district live in rural areas as there is no urbanization. The district accounted for the second lowest population for any district in India in 2001 census and is the least populous district in the country according to the 2011 census since its population has declined from 33,224 in 2001 to 31,528 in 2011.

The people of Lahaul and Spiti are both Hindus and Buddhists, and their dialect is Indo-Tibetan. These people have a close affinity with Ladakhis and Tibetans. The people and the culture in the region evolved over the centuries largely isolated from the rest of the world. In 1992-93, Government of India lifted all the restrictions, including for foreigners, for travelling into the ancient Kingdom of Lahaul and Spiti, that has been virtually forbidden to outsiders for over 30 years since 1962 i.e. during Indo-China war. 
Geographical Analysis of Geotourism Based Seasonal Economy in Lahaul and Spiti, Himachal Pradesh (India)




The main source of livelihood for the people are agriculture and allied activities and the main occupations include animal husbandry, daily wage earning as labourers in government programs, regular government service, business (mainly shop keeping), crafts like weaving and very few involved in travel and tourism industry which is recently gaining significance in this region. The large scale of tourist influx together with the communities that carry out various businesses and earn seasonal livelihood from geotourism and allied activities during this period, generate a huge demand for refreshments (food, water and other day to day utilities) during their treacherous journey in the difficult terrain of lahaul and Spiti district. This seasonal mechanism of demand is fulfilled by the supply through various "dhabas" (a roadside food stall having bedding and camping facilities for the travellers along with other necessary goods such as wollens, shoes, socks, torch, batteries and edible items) which are lifeline for the commuters, explorers and travellers in the district. The area is characterized by seasonality evident through the fact that these dhabas open every year at the start of the season and continue throughout the four months with reinforced supplies from the Kullu and Kinnaur districts as the roads are open and transportation is easily available. They have a unique setup in which food and shelter both are available for the guests with minimal charges. The initial investment required to setup these dhabas, which the owners spend in the hope that the tourism activities will fetch effective and sustainable benefits at the end of the season. After the detailed study of these dhabas in both the Lahaul and Spiti tehsils (administrative units), it has been observed that lahaul tehsil has larger number of guests at their dhabas in comparison to Spiti tehsil. The main reason for this is the manali-leh high way, along which these dhabas are located and thus have greater income levels and dividends. The Lahauli dhabas are far more enterprising than they are in Spiti as Rohtang pass opens earlier than Kunzum pass and intra-district accessibility is almost a month late.

\section{PURPOSE AND METHODOLOGY}

The main objective of the study is to identify and analyse the linkages between geotourism and seasonal economy in Lahaul and Spiti district of Himachal Pradesh.

The study is based on primary data collected during the field visits to lahaul and Spiti during 2017 and 2018. Primary data sources include the field observation tables collected through extensive field survey that includes in-depth interviews and observations through photographs in the study area. For the analysis of the dhaba based economy, an open ended questionnaire based survey was conducted during the various field visits in both opening and closing season in 2017-2018. The sample was based purely on the location in order to understand the relationship of dhaba economy with geomorphosite based tourism and accessibility. The dhabas of Lahaul include the locations such as Gramphu, Tandi, Udaipur, Thirot, Darcha, Zing Zing Bar, Chhatru and Batal while the locations in Spiti include Losar, Kibber, Kaza, Langza, Komic, Tabo, Hurling, Sagnam and Mud. The locations of these places have been mapped using the coordinate points marked through GPS (global positioning system) during the field survey on free source web GIS (geographic information system) software.

\section{RESULTS AND DISCUSSIONS}

In the selected samples of dhabas (i.e. seasonal restaurants with overnight stay facilities for tourists) at field survey sites (Table 1), few of them are found to be running businesses since long time and the most experienced of them are from Lahaul tehsil i.e. about 20-25 years old (Figure 2). It signifies that the opening of the district for outsiders by relaxation of the inner line permits (ILP) in 1992-93 paved way for these seasonal establishments. 
Geographical Analysis of Geotourism Based Seasonal

Economy in Lahaul and Spiti, Himachal Pradesh (India)

Table 1. Field Survey Sites, Lahaul and Spiti, Himachal Pradesh, India (Data source: Primary Survey 2017-2018)

\begin{tabular}{|c|c|c|}
\hline Field Survey Sites & Altitude (msl) & Population (2011) \\
\hline Udaipur & $2661 \mathrm{~m}$ & 1237 \\
\hline Keylong & $3113 \mathrm{~m}$ & 1977 \\
\hline Jispa & $3275 \mathrm{~m}$ & 332 \\
\hline Sissu & $3032 \mathrm{~m}$ & 398 \\
\hline Losar & $4114 \mathrm{~m}$ & 227 \\
\hline Hanse & $3988 \mathrm{~m}$ & 214 \\
\hline Rangrik & $3717 \mathrm{~m}$ & 738 \\
\hline Kaza & $3693 \mathrm{~m}$ & 1367 \\
\hline Kibber & $4130 \mathrm{~m}$ & 295 \\
\hline Komic & $4536 \mathrm{~m}$ & 114 \\
\hline Dhankar & $3863 \mathrm{~m}$ & 319 \\
\hline Tabo & $3297 \mathrm{~m}$ & 635 \\
\hline Langza & $4437 \mathrm{~m}$ & 137 \\
\hline
\end{tabular}

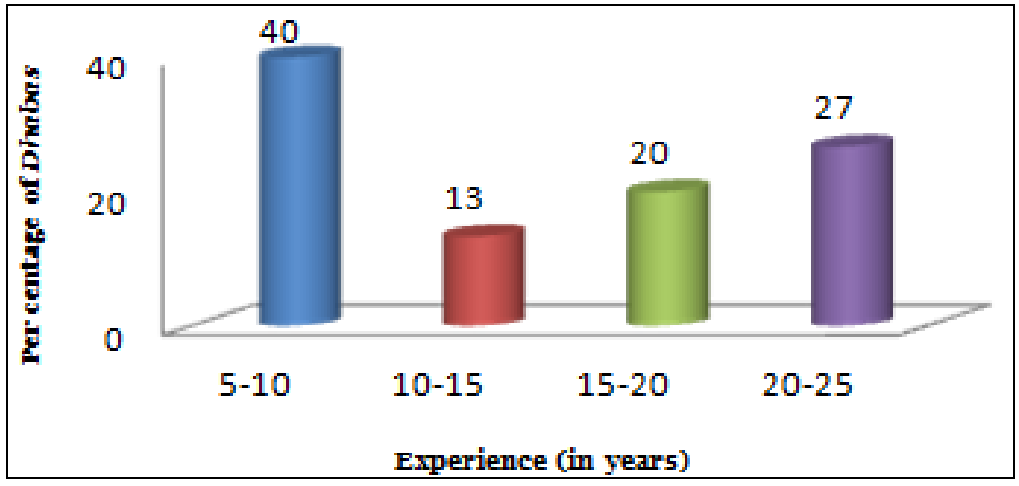

Figure 2. Experience of the Dhaba Owners (Source: Field Survey, 2017-2018)

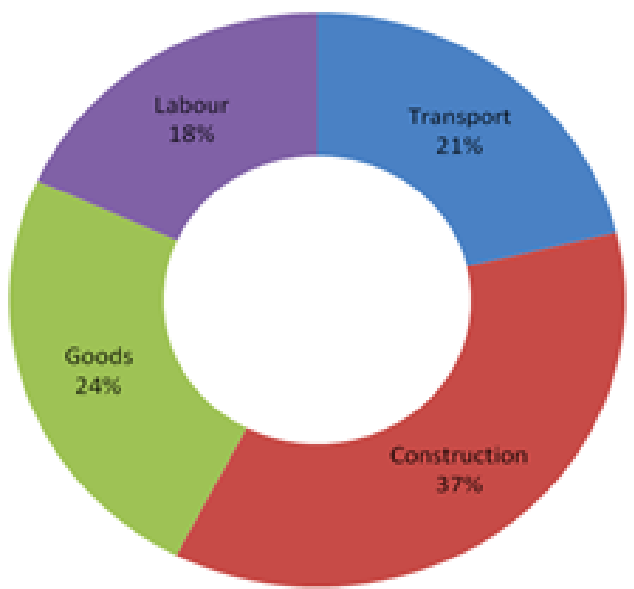

Figure 3. Seasonal Cost of the Dhaba Establishments (Source: Field Survey, 2017-2018)

The most recent ones have come up in last decade or so because of considerable rise in the tourism influx in Himachal Pradesh and Ladakh, mainly due to the reduction of tourism in Kashmir valley because of numerous terrorist issues and incidents. 
Simultaneously, Spiti tehsil also has the older dhabas in the interior locations such as Losar and Kibber while the newer ones are at Tabo and Sagnam due to proximity with Kinnaur.

The establishments have to be renewed every year and the average cost varies between 1 lakh to 1.5 lakh rupees including the transportation cost as well as the other taxes such as electricity and water. Their income per season (excluding all the expenses) varies between 2.5 lakh to 3.5 lakh rupees per season. On an average about 2-3 labourers are engaged for entire season and they are paid about 30-40 thousand rupees per season. The construction, reconstruction and management of the sites together with the transportation charges account for the majority of the cost in the seasonal establishments (Figure 3). As evident from the collected data during field survey, the commodities that these dhabas offer to the customers include maggie noodles (Rs. 20-25 per plate), tea (Rs.10 per cup), coffee (Rs. 25 per cup), dal chawal (Rs. 40-50 per plate), rajma chawal (Rs. 60-70 per plate), Momos (veg. at Rs. 50 -80 per and non veg. at Rs. 80 per plate), mutton chawal (Rs. 80-90 per plate), local beer and wine (Rs. 80-150 per bottle), biscuits, chips and cold drinks (at Rs.10 higher than the cost price) and the mineral water or package drinking water (at Rs. 50-60 per bottle). These prices vary on an average of Rs. 10 per item from place to place. The charges for accommodation vary between Rs.100-150 per night per person per bed at these dhabas. Most of these dhabas have an accommodation capacity of 12-15 personsper night. The tough terrain and treacherous journey has a tiring and draining impact on the outsiders and hence they are willing to pay these prices without any bargaining. Although, some of the dhaba owners in Lahaul prefer foreigners over Indian tourists as they don't bargain and are more stable in terms of stay and payment. They also sell handmade woolen socks, caps, mufflers and gloves at varying prices between Rs. 150-300 at different sites.

The issues and the challenges as highlighted during the interviews with dhaba owners are mainly ascribed to the difficulties in restoration of these temporary structures, construction of newer ones in many cases and the transportation of the goods to these remote areas. They hire mules in few cases while the most of them hire tempo travellers and tractors that are very expensive. Secondly, the problem of labour is faced specially by the local dhaba owners, as they have to negotiate with the season labourers coming mostly from Nepal and other states of India such as Bihar, Odisha and Uttar Pradesh, who charge them heavily for construction work. They build these structures using tent, locally available boulders and rocks, local wood (usually poplar trees) and in some cases with tin shades for roofing.Another significant issue that is highlighted during the field survey includes the ratio of these seasonal establishments between the locals and the outsiders. Analysis of the sample data gives the result that 60 per cent of these dhabas are run by people from Nepal and lower Himachal Pradesh like Mandi and Bilaspur. This leads to the monopoly of the outsiders who have better access to technology and resources and hence the locals who are poor in resources have to suffer as there is tough competition in the business especially during the peak season of June and July when there is maximum tourist influx. The locals have to depend on the external middlemen and labour contractors for the goods and services every season and hence their income levels are less than the outsiders. The price manipulation, lucrative offers for stay and meal together with the customer relations play significant role in the success of the business.

Asha Bodh, aged 39, resident of Gemur village in Lahaul, who is widow with all the family responsibilities on her, gets the only income from the seasonal dhaba at Jispa where many foreigners stay because of the trout fishing and other activities such as nature camps and cultural festivals (Buddha purnima celebrations). She lamented that "the Nepalis win over the local in this business as they have larger labour force and bigger 
Geographical Analysis of Geotourism Based Seasonal

Economy in Lahaul and Spiti, Himachal Pradesh (India)

establishments. They hire vehicles at lower prices than us and also manipulate prices too often to attract customers which affects our business. . . .we have to pay heavily for the reinstallation of the private water pipes sold by the outsiders every year and the electricity charges for the temporary commercial meter installation at the own expense of wire is 8 to 10 thousand with a monthly fixed tax of Rs. 1000 apart from the additional tax on land i.e. Rs 2000 levied by the panchayat ... "(Figure 4).

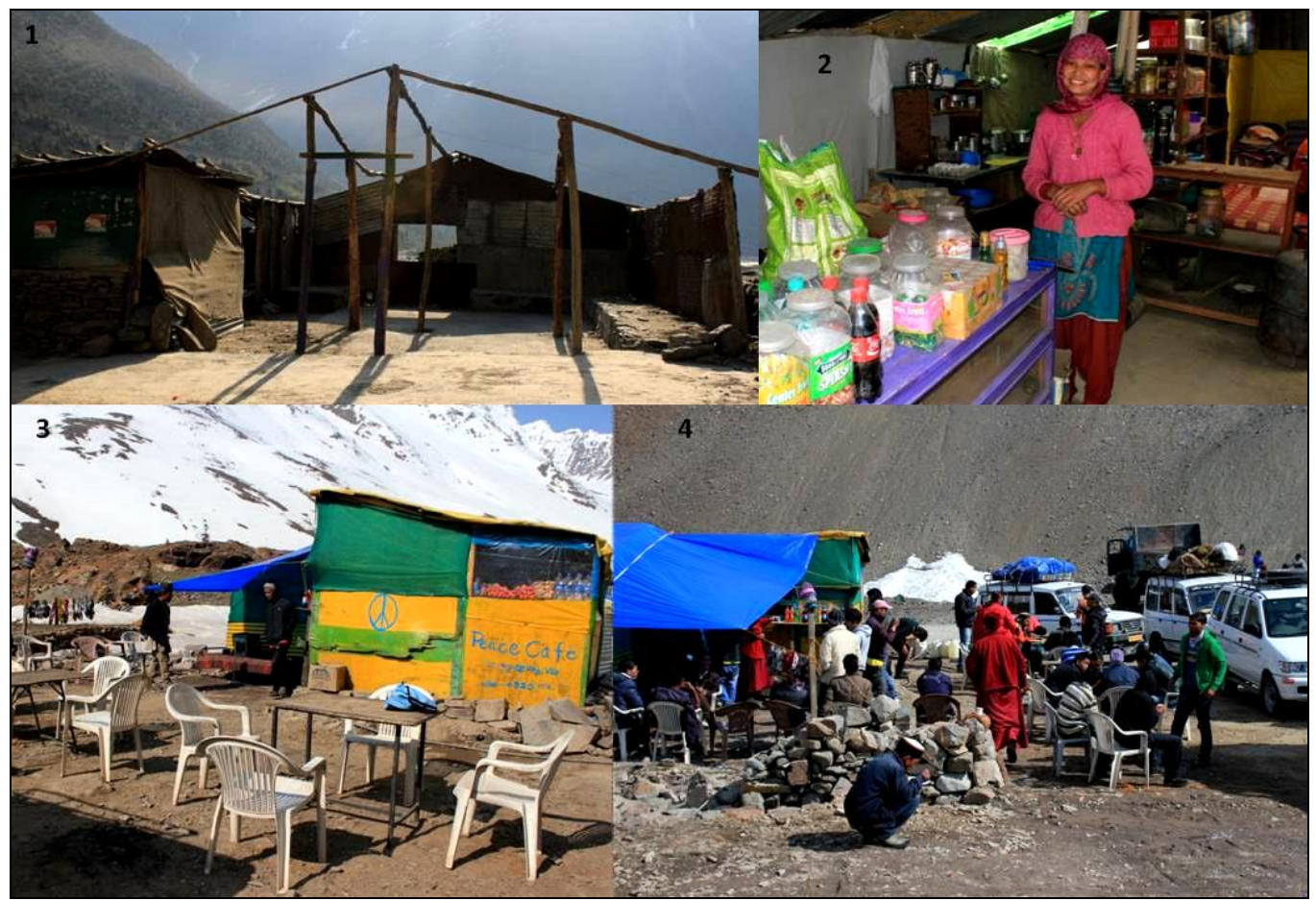

Figure 4. Field Survey Sites (dhabas) Coordinates

1. Dhaba under construction at Darcha village - N32 40.323, E77 11.8; 2. Sonam in her Dhaba at Jispa - N32 37.985, E77 10.585; 3. Peace cafe at Zing Zing Bar - N32 47.246, E77 20.901;

4. Tourists at Chandra dhaba, Batal - N32 21.493 E77 37.148 (Source: Field Survey, 2017-2018)

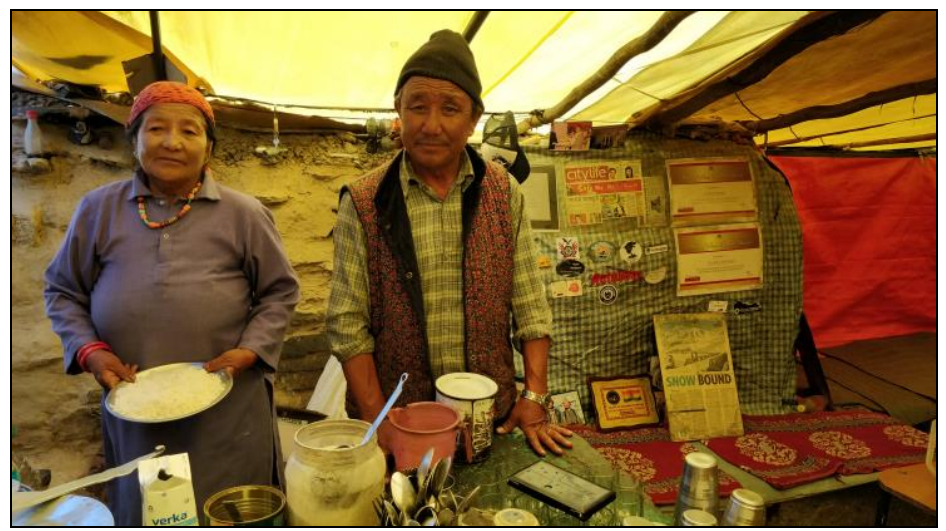

Figure 5. Chandra Dhaba, Batal, Coordinates: $32.3504^{\circ} \mathrm{N}, 77.6170^{\circ} \mathrm{E}$ (Source: Field Survey, 2017-2018) 
The other important issues are the government facilities of health and sanitation. The toilet and medical facilities are not available at most of these sites and the owners themselves have to make arrangements for the same, that becomes a burden in many cases due to financial crunch. The rising prices of the fuel i.e. gas and kerosene also becomes significant as many of them were found to be dependent upon the purchase of this fuel from the brokers who earn profits by selling them at much higher prices than original, in the name of inaccessibility and remoteness of the area. The problem of waste disposal has become alarming by the advent of increasing tourism in last decade. There is lack of dustbins and disposal sites for the large amount of biodegradable as well as nonbiodegradable waste, of which the plastic bottles and the wrappers have the largest share. Hence, mostly they are disposed off and buried in the locally created pits at the end of the season. The role of climate also becomes very significant as the delayed opening of the passes due to late snowfall often result in lesser business opportunities and lesser time for maximum earning. When asked about the significant changes observed by the owners in last decade, the most significant answer was the increase in number of tourists and considerable growth in business. Hence, they are not willing to switch to any other profession during the season. During off season, the outsider owners go back to their respective base locations and perform labourer jobs and selling of woolen clothes and handicrafts. Many locals also migrate to lower Himachal Pradesh during harsh winters and sell handmade woolen garments. According to an article "Saviour-couple-of-Spiti valley, 2010", Bodh Dorjee also known as Kakoo, aged 55 at Batal has the biggest and oldest establishment. He comes with his wife Chandra Dorjee (Figure 5) and few workers during the onset of season when even the motorable roads are not open by hiring mules and stays till late end of the season every year. He has been given a satellite phone by the government in order to serve the locals and the research expeditioners who work on glaciers and glacial lakes in the area. He is a recipient of bravery award for saving lives of expedition team who were tuck in harsh weather condition and is well known among the Lahaul and Spiti district.

Off season, he goes back to Delhi and stays at Majnu ka tilla (a place of Tibetan refuge in Delhi) i.e. Aruna Nagar Tibetan colony with his relatives. The unpredictability of the weather and seasonality in the nature is further emphasized as they narrated the story of a group of 17 trekkers who were stranded for over 10 days at Batal in the month of May in 2010 due to a massive and unexpected snowstorm. They helped the group before a rescue unit of they could airlift them out of the area. He has been featured in TOI (Times of India) newspaper for his unique dhaba and services to the travellers in this treacherous terrain. The main obstacles in geotourism development as pointed out during the tourist surveys, emphasize upon the poor quality of roads and transport facilities and complemetary difficult terrain. Only a small fraction of tourists also referred to harsh climate, lack of medical facilities and remote location as hinderances for geotourism in the area. Some of the very important features of geodiversity like fossils, glacio-fluvial deposits, lacustrine sediments, unnamed waterfalls, highest settlements on almost vertical slopes and many more such features that may allure any tourist from outside the district. The tourism based on these geomorphosites, have immense potential to generate livelihood opportunities and strengthen the economic conditions of the local people in the region.

It is always a pleasure to reach Chandra Dhaba at Batal because that means lunch and meeting the owners of the Dhaba. Their son Tenzing runs a camp at Chandratal (http://traveltalesfromindia.in, 2015). He says that " every year we come here in April on foot and carry the goods on mules from Manali and go back in November first week...I have seen tremendous rise in tourism in last decade and more since the Chandratal was declared as Ramsar site for conservation and management in 2005...every season 
people from various research organizations come here and stay who are working on Samudratapu and Bara Shigri glaciers. . . ".

Similarly, Sonam Bodh, aged 42 at Sagnam in Pin valley, Spiti tehsil owns a dhaba and two floored homestay. He also works as tourist guide for adventure treks across PinParbati pass and for the Pin Valley National Park. He says that "the main hurdle is the accessibility due to the mud flow over the road connecting Attargo and Sagnam which is very unpredictable and government has not taken it seriously enough to build any alternative bridge. This also leads to loss of agro based economy as the harvested peas from Pin valley many times can't reach the market on time and gets rotten. The Shilajeet is main demand of the tourists which we collect from higher altitude while crossing the National Park area and get big returns...also there is menace of cattle predation by snow leopards which attack during the evening and night and no protection has been assured by government in this regards. . .".

Table 2: Geological Formations in Lahaul and Spiti (Data source: Geological Survey of India)

\begin{tabular}{|c|c|c|c|c|}
\hline Era & \begin{tabular}{|c|} 
Time \\
(million \\
years)
\end{tabular} & Age & $\begin{array}{l}\text { Group / } \\
\text { Formation }\end{array}$ & Lithology \\
\hline Cenozoic & 1.8 & Quaternary & $\begin{array}{l}\text { Fluvial / Fluvio- } \\
\text { glacial / Alluvium }\end{array}$ & $\begin{array}{l}\text { Sand, silt, pebbles, cobbles, } \\
\text { boulders }\end{array}$ \\
\hline Mesozoic & 65 & Cretaceous & $\begin{array}{l}\text { Giumal-Chikkim } \\
\text { Formation }\end{array}$ & $\begin{array}{l}\text { Sandstone, siltstone, shale, } \\
\text { conglomerate }\end{array}$ \\
\hline Jurassic & \multirow{3}{*}{243} & \multicolumn{2}{|c|}{ Spiti Formation } & Shale, sandstone and siltstone \\
\hline Triassic-Jurassic & & \multicolumn{2}{|c|}{ Lilang Group / Kalhel Formation } & $\begin{array}{l}\text { Limestones, shales, dolomites } \\
\text { and sandstones. }\end{array}$ \\
\hline $\begin{array}{l}\text { Permo - } \\
\text { Triassic-Jurassic }\end{array}$ & & \multicolumn{2}{|c|}{ Tandi Group } & Limestone \\
\hline Palaeozoic & 270 & \multicolumn{2}{|c|}{ Devonian to Permian } & $\begin{array}{l}\text { Kuling group; Quartzites, } \\
\text { sandstones and black shales }\end{array}$ \\
\hline \multirow{2}{*}{$\begin{array}{l}\text { Lower Cambrian } \\
\text { to Silurian }\end{array}$} & \multirow{2}{*}{570} & \multicolumn{2}{|c|}{$\begin{array}{l}\text { Kunamla-Thango-Takche } \\
\text { Formation }\end{array}$} & $\begin{array}{l}\text { Shale, schist, sandstone, } \\
\text { dolomite }\end{array}$ \\
\hline & & \multicolumn{2}{|c|}{ Rohtang Granitoid } & Granitoids \\
\hline Proterozoic & 670 & \multicolumn{2}{|c|}{$\begin{array}{l}\text { Neoproterozoic to Terminal } \\
\text { Proterozoic }\end{array}$} & $\begin{array}{l}\text { Batal formation, shales, } \\
\text { phyllites and quartzites }\end{array}$ \\
\hline Neoproterozoic & 900 & \multicolumn{2}{|c|}{ Manjir Formation } & Sandstone, limestone, shale \\
\hline Neoproterozoic & 1600 & \multicolumn{2}{|c|}{$\begin{array}{l}\text { Bhalai Formation (Salkhala } \\
\text { Group) }\end{array}$} & $\begin{array}{l}\text { Slates, schists, slates, phyllites, } \\
\text { quartzites }\end{array}$ \\
\hline Mesoproterozoic & 2500 & \multicolumn{2}{|c|}{ Vaikrita Group } & Slates, phyllites, quartzites, schists \\
\hline
\end{tabular}

Overall, by the various cost benefit analysis of the seasonal dhaba, it can be said that these are lifelines for the locals as well as the tourists as it is enterprising and source of livelihood for the former while life saving for the later. The geotourism in the region can play a pivotal role for its economic development and seasonal dhaba economy can be a main contributor to this if regulated properly by the local governance. The improved government aid can help locals in sustaining their livelihood and the same time help in the economic growth of the district. Geologically, the Spiti Shales are dominated by black sandy Shales that are divided into three units i.e. Chidamu beds, Belemnites beds and Lochambal beds that are rich in fossils. The uppermost unit ranges in age from uppermost Jurassic into the lowermost Cretaceous and is richest of the three in varied ammonite fauna that is generally found in the rounded nodules known as "saligrams" in Sanskrit (shale in English). The geographical uniqueness and distinctiveness is entirely 
based on the sets of geological attributes (Table 2, Figure 6). The occurrence of similar fluvio-glacial deposits has also been reported in parts of Spiti. Small unconsolidated deposits of illuvial and glacial origin, occurring throughout the region is clearly visible along side the river. The remnants of terrace deposits have been found along the valley sides and most of the recent gravel and boulder beds occur along the rivers bed. The geographical uniqueness and distinctiveness is entirely based on the sets of geological attributes.

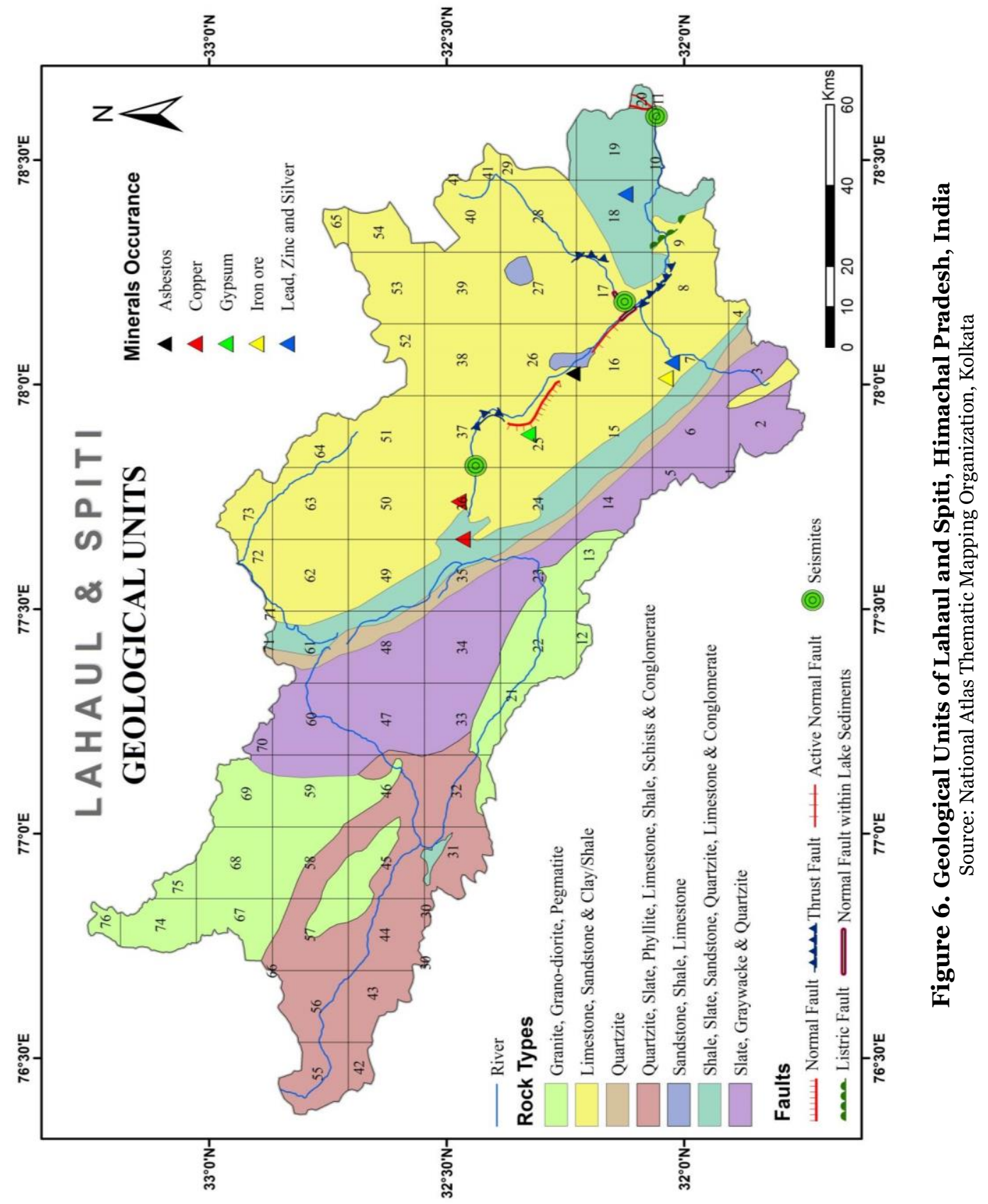


Langza village (4437 mts. above msl) in Spiti valley, considered to be one of the highest villages in the world connected with a motorable road is enriched with ammonite fauna i.e. cephalopod fossils. Locally, it is also known as fossil village and attracts tourists who come looking for pre-himalayan formation fossils. Although possession and collection of fossils are illegal in India, the locals in the village sell these collectibles to the travellers visiting their village. Local people can be seen around the village collecting and displaying fossils in order to persuade the travellers to buy them in return for money. The local name of fossil in the village is 'chaudua' (Figure 7). In Spiti valley, the fossiliferous Spiti Shales are exposed near the villages named Gete, Kibber, Komic, Rangrik and along the sides of Pin river (a tributary of Spiti river).

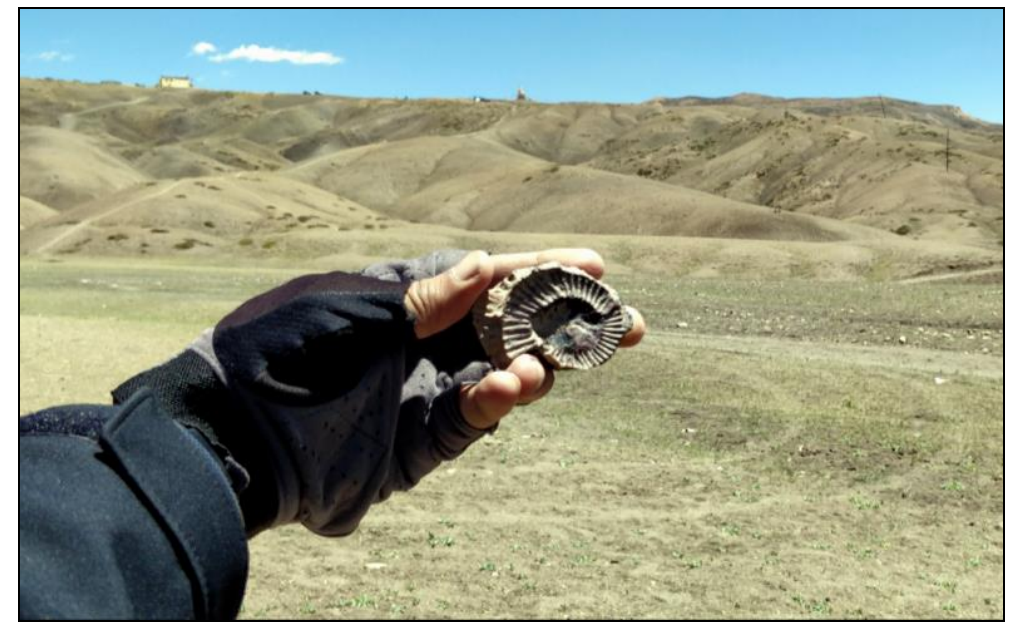

Figure 7. Langza Fossil (saligram) Coordinates: $32.2738^{\circ} \mathrm{N}, 78.0816^{\circ} \mathrm{E}$ (Source: Field Survey, 2017-18)

\section{Strength Weakness Opportunities and Threat \{SWOT\} Analysis for Lahaul and Spiti}

Strength: Beautiful, cold desert landscape surrounded by mountain passes on all sides; source of major glaciers, glacial lakes and rivers; indigenous knowledge preserved; cultural uniqueness (Buddhist practices); unique floral/faunal diversity.

Weakness: Vulnerable to natural hazards and seasonal in character; lack of awareness among the planning bodies; lack of awareness among the research fraternities; remote landscape restricts the cultural interface from other areas; lack of Awareness amongst the tourists as well as planners.

Opportunities: Immense Geotourism potential in the region with the modern technological development.; immense potential to harness the hydropower, water rafting and other sports activities; the knowledge can be harnessed and cure for many ailments can be discovered in the region; immense cultural tourism potential (Ancient monasteries and cultural practices; immense potential to create a Geo/Eco park/Fossil park at the highest villages connected by motorable roads and thus help in sustainable livelihood generation together with geoconservation.

Threat: Deformation of landscape due to increasing developmental pressures; ecological balance may be disturbed without proper research and development methods; loss of knowledge due to ageing population and outmigration of the youth; unchecked tourism and influence from outside may fade the cultural uniqueness over time; degradation of landscape due to natural and anthropogenic hazards may lead to extinction. 


\section{CONCLUSION}

The geographical analysis of human response to the geomorphosites and geotourism based seasonal economy in Lahaul and Spiti makes it evident that the response manifested by the various human attributes to the stimuli of nature has a dynamic relationship. The geophysical-response mechanism comes to the picture as the mountain passes, seasonality, availability of rocks and boulders, mud together with the water resources provide ample opportunity for the hard working population that use available georesources in the best possible manner to shape their milieu and create livelihood for themselves.

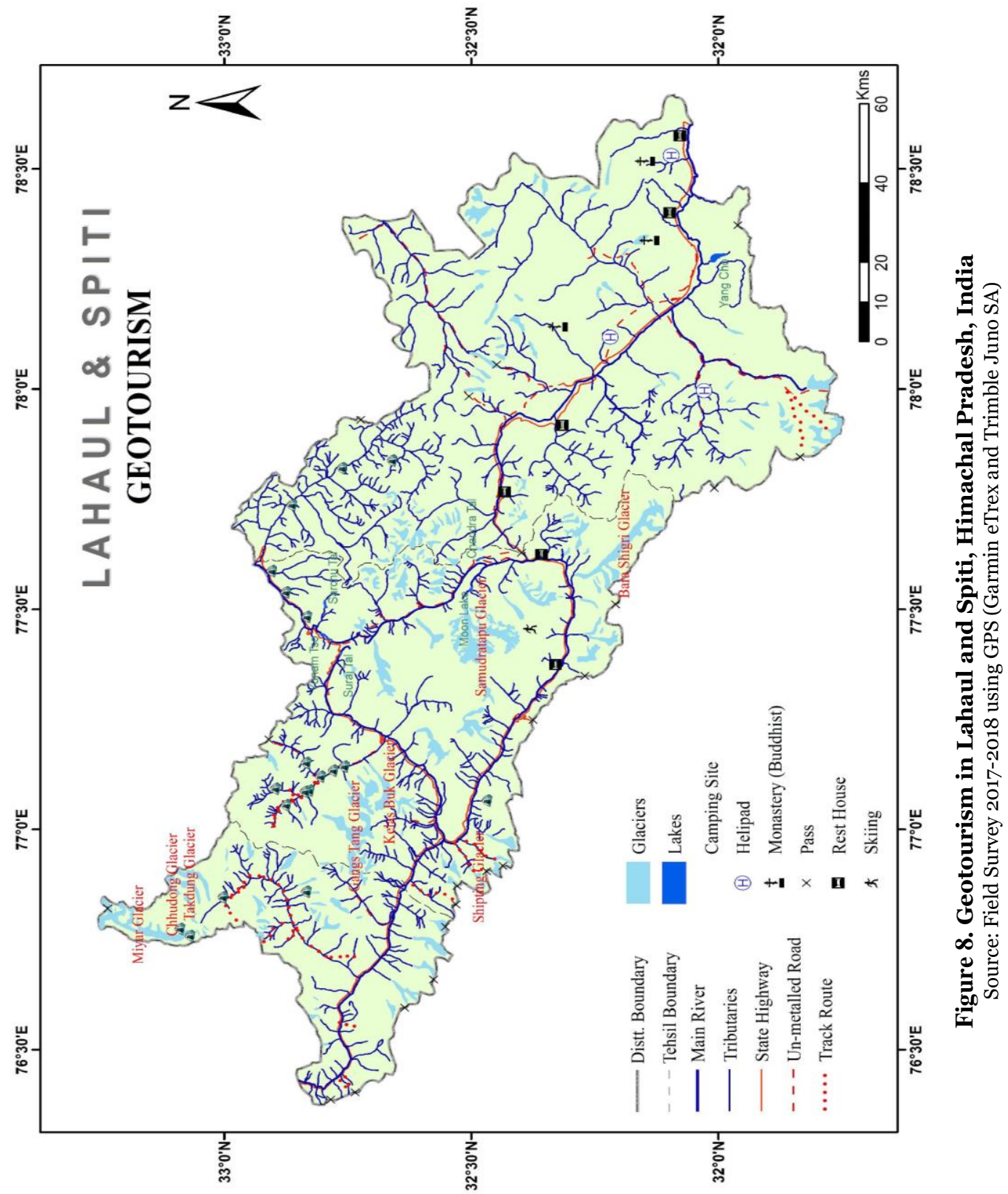


The geomorphosites and geotourism (Figure 8) act as the natural regulatory entities and function respectively for the area that has seasonal character embedded in the lifestyle of the people for centuries. The advent of new technologies in agriculture together with improved communication lines makes the life of the tribal communities easier. The role of government in providing aid and subsides to the poor and marginalized communities has a significant impact on the day to day life of the locals. The tap water facilities and the rural electrification i.e. for 100 per cent of the households certainly seem to ease out the miseries of hash terrain and extreme events.

The role of geotourism is gradually becoming very significant in the district as it has a vast reserve of georesources and geomorphosites that accrue large tourists from all across the world. The glacial lakes, glaciers, snow mountain peaks, hot water springs and the waterfalls are few of many physical features in the landscape that has maximum impact on the geotourism in the region which has evolved and grown over the last decade. The ancient reserves of Tethyan sediments and lacustrine deposits in the area make it a paradise for geoscientists. The exposed rock surfaces, various glacio-fluvial deposits and the associated settlements having unique interface that make the area distinct from other parts of the state of Himachal Pradesh. The role of seasonal dhabas can't be undermined in the economic development of the area as they are lifelines for the travellers, explorers, tourists and geoscientists coming to the area every year. They form an important part in the season economy based on geotourism due to their presence as a facilitator.

The major suggestions for the well being of the betterment of geotourism and seasonal economy in the area are following:

$>$ In the case of mineral extraction, quarrying and road construction many times the important permanent or temporary rock exposures are broken off. In case where these permanently exposed rocks sections are left after completion of the project, the subsequent maintenance of these rock structures should be done.

$>$ Construction of new buildings should incorporate retrofitting to withstand a particular degree of earthquake. Geological and geomorphological inputs must be included in the engineering design as they are extremely important in for site planning.

$>$ The digging of drainage ditches often alters the geomorphological and hydrological character of the area. This accelerates runoff and leads to heavy soil erosion that has to be checked.

> Another interesting observation based suggestion would be that, the footpath erosion caused by trekkers and travellers on steep mountain slopes, initially tramples the seasonal vegetation and ultimately exposes the soil and subsoil. This leads to significant gulleying later. Hence, the trekking routes may be delineated for the vulnerable sites.

$>$ During the open season in Lahaul and Spiti, the potential threat to the landscape in many vital areas like Kunzum pass, have increased with the increasing use of mountain bikes, motorbikes and all-terrain vehicles that often leads to soil compaction, erosion or gulleying on slopes. This needs to be addressed by the road monitoring agencies as well as the local communities.

$>$ Seasonal economy, has to be strengthened in the region through the coordination of local people, self help groups, local government and the NGOs. The potential tourism sites and associated livelihood opportunities have to be further identified and developed.

> The villages such as Darcha and Sarchu in Lahaul valley, and Kibber, Langza, Komic, Gulling, Mikkim and Mud in Spiti valley have fossiliferous rocks. It may be inferred that the region has tremendous potential for establishments of fossil parks and geoparks.

The analysis of geodiversity data may be useful for defining the priority areas for conservation as this methodology may be useful to define the protected areas, 
ecological zones, geoparks etc. Therefore, the Geodiversity Index should be considered as a tool for nature conservation (geoconservation), natural resource management and formulation of geotourism strategies.

At last but not the least, the geophysical stimuli and corresponding human response finds itself the best fit framework to study the geotourism based seasonal economy in the Lahaul and Spiti district due to the cold desert type geotourism, seasonality in opening of passes and the corresponding human response which is essentially seasonal in character. Thus, the seasonal economy of the area is directly linked to the stimuli provided by the geotourism of the area.

\section{Acknowledgement}

The authors are grateful to Shaheed Bhagat Singh College, University of Delhi for institutional support during the research through provsions and facilities at lab and during field work conducted during 2017-2018.

\section{REFERENCES}

Adriansyah, D., Busu, I., Eva, H., \& Muqtada, M. (2015). Geoheritage as the basis for geotourism development: A case study in Jeli District, Kelantan, Malaysia, GeoJournal of Tourism and Geosites, Year VIII, no. 1, Vol. 15, pp 25-43.

Coratza, P., Bruschi, V., M., Piacentini, D., Saliba, D., \& Soldati, M. (2011). Recognition and Assessment of Geomorphosites in Malta at the Il-Majjistral Nature and History Park, Geoheritage, Vol. 3, Issue 3: $175-185$.

Dowling, R., K. (2011). Geotourism's Global Growth, Geoheritage, Vol. 3, Issue 1: 1-13.

Dowling, R.K. \& Newsome, D. (eds.) 2006. Geotourism. Elsevier, Oxford.

Dowling, R.K. 2008a. The Emergence of Geotourism and Geoparks. Journal of Tourism, 9(2), 227-236.

Fakhri, S., Hadaei, \& M., Rahimi, S. (2013). Assess the area geomorphosite Maranjab in tourism development by comparing models, Journal of applied geomorphology, Vol. 1: 89- 104.

Gray, J.M. (2004). Geomorphological conservation and public policy in England: A geomorphological critique of English Nature's 'Natural Areas' approach. Earth surface Processes \& Landforms, Vol. 26, pp 1009-1023.

Hassan, S., S., Andrzej, K., \& Einafshar, A. (2012). A tourism demand based method of geosites assessment on prioritization modeling: The case of Razavi Khorasan Province, Journal of Hospitality Management and Tourism, Vol. 3(5), pp.82-94.

James, H.C.L \& Hose, T.A. (2008). Are We in Danger of Losing the "Geo" in Geotourism? An assessment of the geological potential of selected sites in southern-central Britain. In: Dowling, R.K. \& Newsome, D. (eds.), Geotourism. Proceedings of the Inaugural Global Geotourism Conference, 'Discover the Earth Beneath our Feet', Fremantle, Western Australia, 17-20 August. Promaco Conventions Pty, Ltd., 199-208.

Neches, Irina-Maria. (2013). From Geomorphosite Evaluation to Geotourism Interpretation. Case Study: The Sphinx of Romania's Southern Carpathians, GeoJournal of Tourism and Geosites, Year VI, no. 2, Vol. 12, November 2013, pp. 145-162.

Panizza, M. (2001). Geomorphosites: Concepts, methods and examples of geomorphological survey, Chinese Science Bulletin, Vol. 46, Supplement 1, January 2001, pp. 4-5.

Pereira, P., Pereira, D., \& Caetano Alves, M. (2007). Geomorphosite assessment in Montesinho Natural Park, GeoActa, Special Publication1:170-181.

Pica, A., Vergari, F., Fredi, P., \& Del Monte, M. (2016). The Aeterna Urbs Geomorphological Heritage (Rome, Italy), Geoheritage, Volume 8, Issue 1: 31-42.

Reynard, E. (2005). Géomorphosites et paysages, Géomorphologie: relief, processus, environnement, nr. 3/2005, pp. 181-188.

Shayan, S., Sharifikia, M., \& Zare, GR. (2011). Assessment potential Geomorphotourist Based on Pralong method Case Study: Darab Township, Journal of Arid regions geographic studies, Vol. 5: 73-91.

Yamani, M., Negahban, S., Rahimi, S., \& Alizadeh, M. (2012). Compared geomorphosite and evaluation methods in tourism development (Case study: Hormozgan), Journal of Tourism Planning and Development, Vol. 1, Issue 1: 104-83.

http://traveltalesfromindia.in/2015/o8/postcards-from-lahaul-and-spiti.

http://timesofindia.indiatimes.com/2010/india/Saviour-couple-of-S.

Submitted:

30.11.2018
Revised:

28.01.2019
Accepted and published online 30.01.2019 